\title{
INEQUALITIES FOR A SIMPLEX AND ANY POINT
}

\author{
Li XiaOyAn, Leng GANGSONG AND TANG LiHUA
}

\begin{abstract}
By applying an analytic inequality and the polar moment of inertia inequality in $E^{n}$, we establish some inequalities for the volume, facet areas and distances between any point of $E^{n}$ and vertices of an $n$ - simplex
\end{abstract}

Mathematics subject classification (2000): 52A40, 52A20.

Key words and phrases: Simplex, moment of inertia, mass-point system, volume inequality.

\section{REFERENCES}

[1] M. M. ALI, On some extremal simplexes, Pacific J. Math. 33, (1970), 1-14.

[2] J. CHEN, I. Yong AND S. XIA, A note on generalizations of Neuberg-Pedoe inequalities to $E^{n}$, J. Sichuan University (Natural Science Edition) 36, (1999), 197-200.

[3] L. Fejes Tó TH, Regulare Figuren, Akad é miai Kiad ó, Budapest, 1965.

[4] L. GERBER, The orthocentric simplex as an extreme simplex, Pacific J.Math. 56, (1975), 97-111.

[5] Y. HUANG, An generalization of Neuberg-Pedoe inequality for simplies, J. Yanan University (Natural Science Edition) 18, 3 (1999), 19-22.

[6] M. S. Klamkin, Geometric inequality via the polar moment of inertia, Math. Mag. 48, (1975), $44-46$.

[7] M. S. KLAMKIN, Problem 77-10, SIAM Rev. 20, (1978), 400-401.

[8] G. S. LENG, D. H. WU AND Y. G. ZHOU, Inequalities for vertex distances of two simplices, J. Math. Anal. Appl. to appear.

[9] G. S. LENG, L. TANG, Some generalizations to several dimensional of the Pedoe inequality with applications, Acta Math. Sinica 40, (1997), 14-21.

[10] G. S. LENG, X. QIAN, Inequalities for any point and two simplices, Discrete Math. 202, (1999), $163-172$.

[11] D. S. Mitrinović, J. E. PeČArIĆ, About the Neuberg-Pedoe inequality and Oppenheim inequalities, J. Math. Anal. Appl. 129, (1988), 196-210.

[12] D. S. Mitrinović, J. E. PeČARIĆ AND V. VolenneC, Recent Advances in Geometric Inequalities, Kluwer Acadamic Publishers, Dordrecht, 1989.

[13] D. Pedoe, An inequality and two triangles, Proc. Camb. Phil. Soc. 38, (1942), 397-398.

[14] C. M. PetTy, D. WATERMan, An Extremal Theorem for $n$ - simplexes, Monatsh, Math. 59, (1955), 320-322.

[15] H. SHI, The generalization of a analytic inequality, Bull. Chinese Inequalities Res. Group 26, 3 (2000), 6-8 (in Chinese).

[16] D. SLEPIAN, The Content of Some Extreme Simplexes, Pacific J. Math. 31, (1969), 795-808.

[17] D. VELJAN, The sine theorem and inequalities for volumes of simplices and determinants, Linear Algebra Appl. 219, (1995), 79-91.

[18] T. XU, On generalizations of a analytic inequality, Bull. Chinese Inequalities Res. Group 29, 1 (2001), 11-13( in Chinese).

[19] L. YANG, J. Z. ZHANG, A generalization to several dimensions of the Neuberg-Pedoe inequality with applications, Bull. Australian Math. Soc. 27, (1983), 203-214.

[20] J. Z. ZHANG, L. YANG, A class of geometric inequalities concerning the mass-point systems, J. China Univ. Sci. Technol. 11, (1981), 1-8(in Chinese). 